\title{
MEMBANGUN TEORI KONSUMSI ISLAMI MELALUI MODEL INFAK
}

\author{
Ahmad Anas \\ Afaful Ummah \\ Universitas Muhammadiyah Surabaya \\ Email: anazahmad67@gmail.com
}

\begin{abstract}
This study was based on the assumption that Islamic concumption theory which exists today is result from combination between conventional concumption theory and Islamic religion theory. Conventional concumption theory has many limitations and incompatibility with Islamic teachings and ethics concumption. This study aims to build Islamic concumption theory through infak model. Infak model which is not only materialist, but shar'i, spiritualist, socialist, fair, moral and ethical is believed to be very compatible with the characteristics of Muslim consumers. This study is a type of library study that requires philosophical and theoretical studies that have to do with empirical facts. Results of study showed that Infak of consumption is an activity to spend wealth in an effort to fulfil the needs for the benefit of the world and the hereafter. In infak of concumption activities, consumers must pay attention to limitations that cover two important components, namely Islamic law and ethics. Then infak model explains the level of priority that is the theory of consumer decision making in spending wealth. Furthermore, the purpose of consumption in infak of consumption includes two components; material satisfaction and prosperity in hereafter. Both components are contained in a term called "maslahah".
\end{abstract}

Keywords: Islamic; concumption; Infak model.

\section{PENDAHULUAN}

Terbentuknya teori ataupun konsep ekonomi Islami merupakan respon para cendikiawan muslim terhadap berbagai macam permasalahan ekonomi yang terjadi di masanya. Hal ini mengindikasikan bahwa munculnya teori ataupun konsep ekonomi Islami bersamaan dengan munculnya Islam itu sendiri. Maka tidak salah jika Nejatullah Siddiqi dalam Karim (2012) menyatakan bahwa segala macam kebijakan dan praktek ekonomi yang terjadi di masa Rasulallah dan AlKhulafa Al-Rasyidun merupakan contoh empiris yang dapat dijadikan pijakan oleh cendikiawan muslim setelahnya dalam menemukan dan melahirkan teori dan konsep ekonomi Islami.

Namun teori ataupun konsep ekonomi yang dianut umat Islam saat ini diklaim merupakan hasil dari kombinasi antara ilmu ekonomi murni (konvensional) dan ilmu agama Islam. Paradigma ekonomi Islam didominasi oleh paradigma ekonomi neo-klasikal berbasis fiqh (fiqh based neo-classical economics) dengan menggunakan pendekatan akomodatifmodifikasi (accommodative-modification) serta kaidah memilih dengan bermetode (methodologic eclecticism). Dengan demikian paradigma ini mencampuradukkan antara elemen ekonomi neoklasikal dengan kaedah-kaedah Islam (Salleh, 2011).

Teori konsumsi Islami merupakan salah satu teori ekonomi Islami yang diklaim mengadopsi teori konsumsi konvensional dalam pembentukan teorinya. Diklaim hingga kini, teori konsumsi Islami masih berpedoman pada teori konsumsi konvensional sebagai dasar pembentukan teorinya serta sebagai instrument dalam 
menganalisis perilaku konsumen muslim (Khan, 2013; Muhammed, 2011).

Banyak kalangan yang mengkritik bahwa teori konsumsi konvensional memiliki banyak keterbatasan dan ketidakcocokan dalam menjelaskan perilaku konsumen muslim. Konsumsi konvensional diyakini bersifat individualis yang selalu berfokus pada kepuasan duniawi semata dan hanya dibatasi oleh angka anggaran (Muhammed, 2011).

Penelitian yang dilakukan oleh Rahim \& Bahari (2018) yang bertujuan mengevaluasi teori konsumsi keynes dalam perspektif Islam membuktikan hal tersebut. Teori konsumsi Keynes berasumsi bahwa rumah tangga akan meningkatkan konsumsinya jika pendapatannya meningkat. Peningkatan konsumsi akan meningkatkan permintaan rumah tangga yang kemudian akan berkontribusi pada pertumbuhan ekonomi. Hasil penelitian menunjukkan bahwa teori konsumsi Keynes memiliki keterbatasan dan kelemahan jika dibandingkan dengan ajaran-ajaran berkonsumsi dalam Islam. Teori konsumsi Keynes memotivasi individu untuk berkonsumsi berlebihan. Dampaknya secara otomatis akan menyebabkan tingkat hutang yang tinggi, masalah kemiskinan, dan distribusi pendapatan yang tidak seimbang yang selanjutnya akan menghambat pertumbuhan ekonomi nasional.

Khan (2013) dalam penelitiannya yang berjudul "An Alternative Approach to Analysis of Consumer Behaviour: Need for Distinctive 'Islamic' Theory" mengklaim bahwa teori perilaku konsumen konvensional yang menjadikan keinginan dan kepuasan sebagai dasar dan tolak ukur teori perilaku konsumen tidak dapat menunjukkan dan memahami perilaku konsumen muslim secara komprehensif, bahkan perilaku konsumen barat sendiri. Sebagai contoh, mengapa konsumen lebih memilih untuk membelanjakan barang mewah yang mencolok sementara kebutuhan dasarnya tidak terpenuhi. Khan (2013) berpendapat bahwa dalam memahami perilaku konsumen seharusnya didasarkan pada kebutuhan, bukan pada keinginan yang berimbas pada kepuasan. Karena secara rasional manusia akan memprioritaskan kebutuhan dari pada keinginannya demi mendapat kesejahteraan yang merupakan tujuan utama hidupnya.

Berdasarkan keterbatasan dan ketidakcocokan tersebut, beberapa ekonom muslim modern berusaha mengembangkan model teori konsumsi konvensional sehingga dapat dianggap sebagai teori konsumsi Islam yang sesuai dengan ajaran-ajaran Islam. Seperti Khaf (1995) dan Agil Sayed Omar dalam Muhammed (2011) yang menyatakan bahwa tujuan konsumsi Islam tidak hanya untuk kepuasan materialis sehingga yang dibelanjakan hanya barang konsumsif saja, akan tetapi harus mencakup kepuasan materil dan kepuasan akhirat kelak. Oleh karena itu, keduanya menambahkan zakat dan sedekah dalam teori konsumsi Islam. Maka persamaannya ditulis sebagai berikut:

$$
\mathrm{Y}=(\mathrm{C}+\text { Infak })+\mathrm{S} \rightarrow \mathrm{Y}=\mathrm{FS}+\mathrm{S}
$$

Keterangan:

$\mathrm{Y}=$ pendapatan

$\mathrm{FS}=$ final spending

$\mathrm{C}=$ konsumsi

$\mathrm{S}=$ tabungan

Beberapa penelitian di atas, telah cukup membuktikan bahwa teori konsumsi konvensional memiliki banyak keterbatasan dan ketidak sesuaian bahkan dalam memahami perilaku konsumsi masyarakat barat sekalipun. Maka atas dasar asumsi tersebut serta upaya untuk menggali dan melahirkan teori ekonomi dari konsep dan paradigma Islam sendiri, peneliti mencoba membangun teori konsumsi Islami melalui "model infak". Model infak yang bersifat materialis, spiritualis, sosialis, beretika, sederhana dan adil diyakini sangat sesuai dengan karakteristik konsumsi dalam Islam sehingga cocok digunakan sebagai instrument analisis dalam memahami 
perilaku konsumen dan teori pengambilan keputusan konsumen.

\section{METODE PENELITIAN}

Penelitian ini adalah penelitian kepustakaan (library research), yang membutuhkan kajian filosofik dan teoritik yang ada kaitannya dengan fakta empirik (Muhadjir, 1996). Maka penelitian ini akan terfokus pada buku-buku klasik karya ulama' klasik dan kontemporer yang ada kaitannya dengan infak dan konsumsi tanpa harus turun ke lapangan.

Sumber data yang digunakan dalam penelitian ini terdiri dari sumber data primer dan sekunder. Dalam hal ini yang dijadikan sebagai sumber data primer adalah mafātihul ghayb, jāmi' al-bayāni fī ta'wīl al-qur'īni, dawrul qiyam wal ahklāq fîl iqtișād al-islāmī, nizām al-iqtișādī fîl Islām, ihyā' ulūmuddīn, Economic Consumption Model Revisited: Infak Based on AlShaybani's Levels of Al-Kasb. Sedangkan sumber data sekunder adalah sumber data tambahan yang yang membahas konsumsi ataupun infak, seperti; jurnal ataupun buku.

Teknik pengumpulan data yaitu dengan menelaah dan memahami semua literatur yang menjadi sumber data primer dan sekunder dengan baik, sehingga menghasilkan data valid yang sesuai dengan apa yang dibutuhkan oleh peneliti. Sedangkan analisis data dalam penelitian ini melalui tahap: reduksi data, penyajian data, penarikan kesimpulan dan verifikasi.

\section{HASIL DAN PEMBAHASAN Pengertian Infak}

Istilah Infak berasal dari bahasa arabb "الإنفاق" yang merupakan masdar dari lafadz "أفقنق"الفعل", Lafadz "أنفق" berasal dari fiil madhi tsulasi mujarrod "نفق" yang bermakna "habis". Dari sini bisa dipahami bahwa lafadz "نفق" merupakan fiil lazim yang bermakna habis, kemudian diikutkan wazan "أفعل "أفع " sehingga menjadi "أنفق" yang bermasdar infak (الانفاق). Sebagaimana yang diketahui bahwa wazan "أفعل "الفل salah satu faedahnya adalah memutaddikan fiil lazim. Maka "أنفق" menjadi fiil mutaaddi sehingga bermakna "menghabiskan" (Az-Zabīdī, n. d. ).

Secara konseptual, infak berarti mengeluarkan atau meyerahkan harta demi memperoleh kesejahteraan baik untuk diri sendiri, keluarga ataupun orang lain (Kahf, 2012). Definisi tersebut secara susbtansi sama dengan definisi Ar-Rāzī (1981) di dalam tafsirnya ketika membahas tafsir ayat 195 surat Al-Baqarah yang menyatakan bahwa infak adalah mentasarufkan/membelanjakan harta kepada segala bentuk kemaslahatan. Kemudian di tempat lain ketika membahas tafsir surat Al-Baqarah ayat 3 menyatakan bahwa infak di dalam ayat mencakup infak wajib dan infak sunnah. Infak wajib memiliki beberapa macam, yaitu: zakat, infak untuk memenuhi kebutuhan diri sendiri dan orang-orang yang nafaqahnya di atas tanggungannya, dan infak untuk berjihad.

Pemaparan di atas menujukkan bahwa infak memiliki makna yang umum, mencakup segala bentuk pentasarrufan atau pembelanjaan harta, baik yang bersifat wajib, seperti: zakat, infak untuk memenuhi kebutuhan diri sendiri keluarga dan lain sebagainya atau pentasarrufan yang bersifat sunnah seperti shadaqah pada umumnya. Sehingga bisa dikatakan bahwa infak mencakup pada makna distribusi kekayaan seperti zakat, shadaqah, pajak dan lain sebagainya dan mencakup pula makna konsumsi, seperti membelanjakan harta untuk kebutuhan diri sendiri.

\section{Kerangka Infak}

Pembahasan ini sangat penting demi memberi pemahaman sekaligus menjawab pertanyaan mengenai relevansi infak dengan konsumsi sehingga dapat diklaim bahwa infak sebagai dasar dalam membangun teori konsumsi Islam. Telah dipahami sebelumnya bahwa infak mencakup segala jenis pentasarrufan harta baik untuk kebutuhan diri sendri, keluarga ataupun orang lain, baik bersifat wajib, 
sunnah ataupun mubah. Maka kerangka model infak sebagai berikut:

Gambar 3. 1 Kerangka Infak

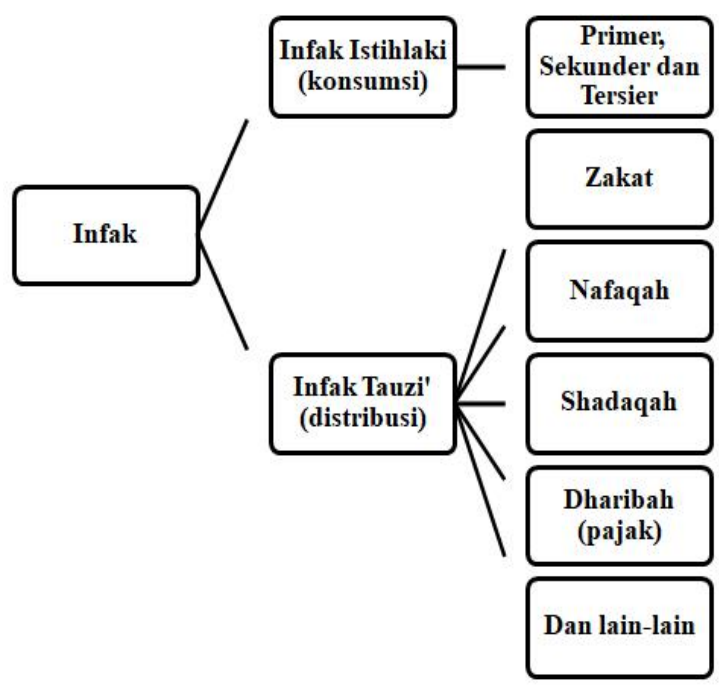

Berdasarkan gambar di atas, nampak jelas bahwa infak mencakup segala jenis pentasarrufan atau pembelanjaan harta, sehingga dapat diketahui bahwa infak tidak hanya bermakna distribusi kekayaan (tawzī'), Akan tetapi infak juga bermakna pentasarrufan/pembelajaan untuk memenuhi kebutuhan diri sendiri. Bagian inilah yang masuk kategori konsumsi atau disebut dengan "infak konsumsi”.

\section{Level Infak}

Pembahasan ini perlu di paparkan karena akan menjadi salah satu dasar utama pembentukan teori konsumsi Islami melalui model infak. At-Tabarī (2001), ArRāzī (1981) Al-Shaybān̄̄ dalam Muhammed (2011), Al-Qarḍāwī (1995), An-Nabhān̄ī (2004) memaparkan level infak sebagai berikut:

1. Infak wajib, adalah jenis pentasarrufan harta yang harus dilakukan oleh setiap individu demi mendapatkan kesejahteraan di dunia dan di akhirat. Infak wajib harus diprioritaskan diatas infak sunnah ataupun mubah. Berikut adalah jenis dan tingkatan infak wajib:

a. Infak untuk diri sendiri, setiap individu harus

memprioritaskan kebutuhan dirinya sendiri di atas kebutuhan lainnya demi kelangsungan hidupnya sehingga ia dapat menjalankan ibadah dan aktifitasnya dengan baik.

b. Infak untuk membayar hutang, Al-Shaybānī dalam Muhammed (2011) menempatkan hutang ditingkatan kedua yang harus diprioritaskan dari infak wajib yang lain. Hutang disini mencakup segala jenis tanggunggan yang harus dilunasi oleh individu, seperti; kredit, tunggakan biaya sekolah anak, ganti rugi barang yang telah dirusak dan lain sebagainya.

c. Nafakah, merupakan kewajiban mutlak bagi setiap individu dalam memenuhi kebutuhan keluargannya. Nafakah dalam Islam dibagi menjadi dua, yaitu: 1) nafakah yang bersifat mutlak tanpa syarat, seperti nafakah terhadap istri dan anak yang belum baligh. 2) nafakah dengan syarat miskin dan tidak mampu bekerja, seperti nafakah terhadap orang tua, kakak, adik, paman dan kerabat lainnya.

d. Zakat, wajib bagi individu untuk mengerluarkan zakat dari sebagian hartanya apabila sudah sampai nisab dan haul.

e. Tabungan, Al-Shaybān̄̄ dalam Muhammed (2011) memasukkan tabungan ke tingkatan infak wajib. Tabungan merupakan hal yang sangat penting demi 


\section{menghadapi kebutuhan- kebutuhan tak terdunga di masa depan.}

2. Infak sunnah, setelah memenuhi kebutuhan dasar untuk diri sendiri, untuk anggota keluarga, melunasi utang, membayar zakat dan menabung, maka direkomendasikan agar ia bershadaqah untuk memenuhi kebutuhan dasar kerabat yang tidak wajib ia nafkahi, tetangga sekitarataupun orang lain yang yang membutuhkan bantuannya.

3. Infak mubah, infak ini mencakup segala jenis infak selain infak wajib dan sunnah, seperti membeli barang atau makanan diluar kebutuhan kebutuhan dasar. Islam memperbolehkan hal tersebut selama tidak keluar dari batasan yang dapat melupakan ibadah kepada Allah. Bahkan Islam memperingatkan untuk tidak terlalu pelit dalam memfasilitasi diri sendiri dengan fasilitas yang baik.

\section{Definisi Infak Konsumsi}

Berdasarkan definisi infak yang telah dipaparkan sebelumnya, sebenarnya telah dapat disimpulkan definisi infak konsumsi. Namun sebelum mengambil kesimpulan tersebut, peneliti mencoba menelaah beberapa literatur cendikiawan muslim yang mendefinisikan infak konsumsi secara khusus.

Peneliti menemukan dua definisi yang mendekati pada pengertian infak konsumsi, yaitu definisi Al-qarḍāwī dan An-nabhānī. Al-Qarḍāwī (1995) mendefinisikan infak konsumsi sebagai suatu faktor yang mendorong kelompok tertentu untuk melakukan kegiatan produksi sehingga dapat memenuhi kebutuhan dan keinginan. Sedangkan AnNabhānī (2004) menyatakan bahwa infak konsumsi adalah upaya pemenuhan terhadap kebutuhan-kebutuhan yang harus dipenuhi. Berdasarkan pengertian di atas, dapat disimpulkan bahwa infak konsumsi (infak istihlākī) adalah pembelanjaan terhadap harta dalam upaya memenuhi kebutuhan hidup sehingga dapat mencapai kemaslahatan dunia dan akhirat.

\section{Konsep Kebutuhan Infak Konsumsi}

Kebutuhan merupakan faktor utama terjadinya kegiatan infak konsumsi. Oleh karena itu, dibagian ini peneliti akan memaparkan konsep kebutuhan dalam infak konsumsi. Adapun definisi kebutuhan mungkin dapat dipahami secara implisit melalui kandungan surat AlFurqan ayat 67 :

\section{"Dan orang-orang yang apabila membelanjakan (harta), mereka tidak berlebihan, dan tidak (pula) kikir, dan adalah (pembelanjaan itu) di tengah-tengah antara yang demikian"}

Ayat di atas menganjurkan keadilan dalam mentasarrufkan atau membelanjakan harta, tidak berlebihan dan tidak terlalu menahan. Maka bisa dipahami bahwa kebutuhan dalam infak konsumsi adalah tengah-tengah (tawassut) antara berlebihan dan terlalu menahan.

At-Tabarī (2001) memaparkan beberapa pendapat ahli tafsir dari sahabat nabi mengenai tafsir lafadz israf dan taktir, kemudian mengunggulkan pendapat yang menyatakan bahwa israf dalam infak yang dikendaki dalam ayat adalah sesuatu yang melampaui batas yang diperbolehkan oleh Allah SWT untuk hamba-hambanya. Sedangkan taktir adalah sesuatu yang menyebabkan kecerobahan dalam menjalankan perintah Allah dan qawam adalah diantara keduanya. Seperti seseorang memakan makanan melampaui batas kenyangnya sehingga melemahkan badannya untuk beribadah kepada Allah SWT. Maka seseorang tersebut dinamakan musrif (berlebihan). Kemudian jika orang tersebut tidak makan sama sekali sehingga melemahkan badannya, untuk beribadah kepada Allah SWT, maka itu yang dinamakan taktir (menahan). Maka 
diantara keduanya itulah yang dinamakan qawam (adil). Batasan-batasan ini berlaku pada setiap jenis kebutuhan (seperti tempat tinggal, baju).

Berdasarkan pernyataan di atas, maka kebutuhan dalam berinfak konsumsi adalah suatu yang diupayakan manusia untuk bertahan hidup dengan tidak berlebihan (yang dapat menghilangkan kekuatan untuk beribadah kepada Allah) dan terlalu menahan diri (yang dapat melemahkan diri beribadah kepada Allah). Maka sesuatu yang melampaui batas dinamakan keinginan sedangkan terlalu menahan diri dinamakan pelit.

\section{Konsep Maslahah}

Tujuan infak konsumsi adalah untuk mendapatkan kemaslahatan dunia dan akhirat. Kepuasan duaniawi merupakan salah satu tujuan infak konsumsi. Al-Qarḍāwī (1995) menyatakan bahwa memiliki harta memang dianjurkan dalam Islam, akan tetapi hal tersebut hanyalah sebagai wasilah untuk mendapatkan kepuasan terhadap apa yang Allah ciptakan untuk hamba-hambanya yang mana hal tersebut tidak dapat terealisasi tanpa perantara harta. Maka dapat dipahami bahwa orientasi infak konsumsi tak hanya pada kesejahteraan akhirat saja.

Maslahah menurut istilah ulama' adalah manfaat yang dikehendaki Allah untuk hambanya, yaitu menjaga keberlangsungan agama, nyawa, akal, keturunan, dan harta. Dapat dipahami bahwa Allah SWT mengendaki semua hambanya untuk mendapat kemanfaatan, yang mana kemanfaatan tersebut terkandung di dalam perintah dan larangannya, baik kemanfaatan dunia (material) ataupun akhirat (pahala). Manfaat ini mencakup lima tujuan pokok syariat Islam (maqasid syariah), menjaga keberlangsungan agama, nyawa, akal, keturunan, dan harta.

Dari sini dapat dipahami bahwa Konsep utility yang diusung dan dijadikan tujuan utama kegiatan ekonomi oleh ekonom barat telah lebih dulu di usung oleh Islam melalui cendikiwancendikiawan muslimnya beribu-ribu tahun yang lalu atau biasa dikenal dengan term maqasid syariah. Hanya saja konsep utility yang diusung oleh ekonom barat tersebut hanya terfokus pada satu sisi saja, yaitu kepuasan duniawi. Ekonomi barat mengabaikan kepuasan akhirat yang mana justru kepuasan itulah yang akan menjadi kepuasan yang kekal pasca kehidupan dunia.

\section{Level Infak dan Teori Pengambilan Keputusan}

$\begin{array}{rrr}\text { Konsumen } & \text { muslim } & \text { harus } \\ \text { level } & \text { infak } \\ \text { (pentasarrufan/pembelanjaan } & \text { harta) }\end{array}$
sehingga dapat mengambil keputusankeputusan dalam berkonsumsi sesuai dengan ketentuan Islam dan tidak ada pihak yang terdzolimi. Seorang muslim harus memprioritaskan kebutuhan dirinya sendiri dan orang-orang yang menjadi tanggung jawabnya dalam memenuhi kebutuhanya (nafaqah) dan mengesampingkan infak-infak yang bersifat sunnah. Hal ini telah dijelaskan dalam firman Allah dalam surat AlBaqarah ayat 219:

"Dan mereka bertanya kepadamu
apa yang mereka nafkahkan.
Katakanlah Yang lebih dari
keperluan"

Al-Qarḍāwī (1995) menyatakan bahwa ayat tersebut menjelaskan tentang ukuran harta yang harus dinfakkan, kemudian Allah menjawab dengan menggunakan lafadz (العفو) yang mana dalam segi bahasa bermakna "lebihan". Maka kadar yang harus diinfakkan (infak sunnah) adalah harta lebihan atau sisa dari infak wajib. Hal ini juga telah dijelaskan dalam hadist nabi yang diriwayatkan oleh Jabir:

"Diriwayatkan oleh Abi Zubair dan jari bahwa bahwa seorang laki-laki 
anshar yang bernama Abu Madzkur telah membebaskan seorang budaknya yang bernama Ya'qub (dengan syarat ia telah meninggal), dan ia tidak memiliki harta selain budak tersebut. Kemudian Rasulullah shallallahu 'alaihi wasallam meminta untuk membawanya dan bersabda: "Siapakah yang mau membelinya?" Kemudian Nu'aim bin Abdullah bin An Nahham membelinya dengan harga delapan ratus dirham. Beliau lalu menyerahkan uang tersebut kepadanya seraya bersabda: "Jika salah seorang di antara kalian fakir, maka hendaknya ia memulai (sedekah) kepada dirinya sendiri, jika ada kelebihan maka ia berikan kepada keluarganya, jika ada kelebihan maka ia berikan kepada orang yang memiliki hubungan kekerabatan, kemudian jika masih ada kelebihan maka ia bisa memberikannya kepada siapa saja. "(Daud, 2009)

Ayat dan hadis di atas secara jelas menunjukkan bahwa seorang muslim tidak wajib menshadaqahkan atau menzakatkan seluruh hartanya, tetapi ia wajib memenuhi kebutuhan pribadinya terlebih dahulu. kemudian jika ada sisa, diperbolehkan baginya menshadaqahkan atau menzakatkannya. Infak sunnah tidak boleh dilakukan kecuali telah dilaksanakannya infak wajib. Adapun infak wajib memiliki beberapa jenis, seperti konsumsi, zakat dan nafakah (istri dan anak). Dengan berpijak pada level infak yang telah dipaparkan sebelumnya,berikut runtutan prioritas infak:

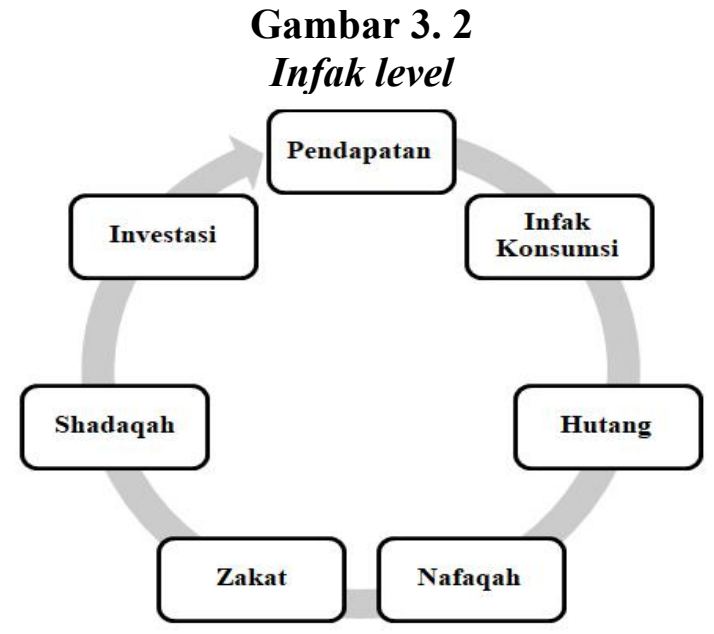

Gambar di atas menunjukkan bahwa kewajiban pertama dalam mentasarrufkan harta adalah seorang konsumen harus memenuhi kebutuhannya sendiri. Kemudian konsumen harus membayar hutang ataupun segala bentuk tanggungan yang diwajibkan kepadanya. Setelah itu, konsumen harus memenuhi kebutuhan keluarga yang menjadi tanggung jawabnya (nafakah). Selanjutnya adalah membayar zakat apabila masih ada sisa dari pendapatan dan memebuhi syarat wajibnya zakat (haul dan nisab), maka wajib membayar zakat. Kemudian apabila tidak memenuhi syarat zakat, maka sebagian harta bisa dishadaqahkan. Terakhir adalah investasi ataupun menabung demi kehidupan masa depan. Inilah runtutan pentasarufan harta (infak) dalam Islam. Berdasarkan tingkatan infak di atas, teori umum infak konsumsi dapat diungkapkan dengan persamaan sebagai berikut:

$$
\mathrm{Y} \quad=\mathrm{I}\left(\mathrm{I}_{\mathrm{c}}+\mathrm{I}_{\mathrm{d}}+\mathrm{I}_{\mathrm{n}}+\mathrm{I}_{\mathrm{z}}+\mathrm{I}_{\mathrm{s}}+\mathrm{I}_{\mathrm{i}}\right)
$$

Keterangan:

$\begin{array}{ll}\mathrm{Y}=\text { pendapatan } & \mathrm{I}=\text { infak } \\ \mathrm{I}_{\mathrm{c}}=\text { konsumsi } & \mathrm{I}_{\mathrm{n}}=\text { nafakah } \\ \mathrm{I}_{\mathrm{d}}=\text { hutang } & \mathrm{I}_{\mathrm{Z}}=\text { zakat } \\ \mathrm{I}_{\mathrm{s}}=\text { shadaqah } & \mathrm{I}_{\mathrm{i}}=\text { investasi }\end{array}$

Teori yang peneliti tawarkan disini dibagun melalui model infak. Teori ini mencakup kepada semua jenis pentasarrufan harta. Dengan ini konsumen 
akan mengetahui keputusan-keputusan dalam prioritas pentasarrufan hartayang sesuai dengan ketentuan Islam sehingga tidak terjadi kedziloman nantinya. Teori ini sangat sesuai dengan karakteristik konsumen muslim yang tidak hanya materialis (kepuasan memenuhi kebutuhan), akan tetapi syar'i (memahami hukum Islam), spiritualis, sosialis, adil, bermoral dan beretika.

Beda halnya dengan teori yang dikemukakan oleh konsumsi perspektif ekonomi Islami melalui sarjana kontemporernya. Seperti Khaf (1995) dan Agil Sayed Omar dalam Muhammed (2011) yang membangun teorinya berdasarkan teori konsumsi konvensional. Mereka menyadari bahwa keterbatasan teori konvensional yang hanya berorentasi pada tujuan individu dan hanya dibatasi oleh garis anggarannya saja, sehingga ia menambahkan infak yang mencakup zakat dan shadaqah. Maka persamaannya ditulis sebagai berikut:

$$
\mathrm{Y}=(\mathrm{C}+\text { Infak })+\mathrm{S} \rightarrow \mathrm{Y}=\mathrm{FS}+\mathrm{S}
$$

Keterangan:

$\mathrm{Y}=$ pendapatan $\quad \mathrm{FS}=$ final spending

$\mathrm{C}=$ konsumsi $\quad \mathrm{S}=$ tabungan

Jika dibandingkan, teori infak konsumsi yang peneliti tawarkan melalui model infak lebih komprehensif dan sesuai dengan tujuan dan prinsip ekonomi Islami yang sebenarnya. Teori konsumsi yang diusung oleh Khaf tidak ada penjelasan secara rinci kepada siapa saja konsumen harus mentasarufkan hartanya kecuali infak (zakat/infak).

\section{Batasan Infak Konsumsi}

Islam telah memberikan ramburambu mengenai batasan dalam infak konsumsi, yang mana hal tersebut merupakan komponen utama yang akan menampakkan perbedaan antara perilaku konsumen muslim dan konvensional. Batasan-batasan tersebut terdiri dari dua komponen, yaitu hukum Islam dan etika.
Berikut batasan-batasan yang harus diperhatikan konsumen muslim dalam melakukan kegiatan infak konsumsi:

Pertama, batasan yang berhubungan dengan sifat dan cara. Konsumen muslim harus benar-benar memperhatikan sesuatu yang diperbolehkan dan dilarang oleh Allah SWT. Setiap konsumen muslimharus mengetahui mana produk yang halal dan haram serta bagaimana cara mendapatkan produk yang dibutuhkan sesuai koridor syariah sehingga produk tersebut halal dikonsumsi. Hal ini telah dijelaskan di dalam surat Al-Baqarah ayat 168:

\section{"Hai sekalian manusia, makanlah yang halal lagi baik"}

Ayat di atas secara jelas memerintahkan para pelaku ekonomi untuk mengkonsumsi makanan yang halal dan baik. Sebagaimana yang diketahui bahwa adanya perintah mengindikasikan wajibnya sesuatu yang diperintahkan. Hal ini juga diperkuat di dalam hadis Nabi SAW:

"Kaki seorang hamba tidak akan bergeser pada Hari Kiamat sampai dia ditanyai: tentang umurnya, dalam hal apa dia habiskan; tentang ilmunya, dalam hal apa dia amalkan; tentang hartanya, dari mana dia peroleh dan untuk apa dia belanjakan; dan tentang tubuhnya, dalam hal apa dia manfaatkan"(At-Tirmidhī, 2011)

Hadis di atas menekankan para pelaku ekonomi agar benar-benar memperhatikan harta didapatnya dan bagaimana membelanjakan atau mentasarrufkan harta tersebut. Maka dari itu para konsumen muslim harus benarbenar peka terhadap barang-barang yang diharamkan sehingga bisa terbebas darinya.

Kedua, batasan yang berhubungan dengan spiritual. Bagi konsumen muslim hendaknya memulai aktifitas konsumsinya 
dengan niat. Dengan meniatkan aktivitas konsumsinya untuk beribadah atau wasilah dalam beribadah kepada Allah SWT, maka ia akan mendapatkan pahala yang merupakan tujuan akhir demi meraih kebahagiaan di akhirat kelak. Hal ini sebagaimana dijelaskan di dalam hadis nabi:

"Sesungguhnya segala amalan
tidak lain tergantung pada niat;
dan sesungguhnya tiap-tiap orang
tidak lain (akan memperoleh
balasan dari) apa yang
diniatkannya. Barangsiapa
hijrahnya menuju (keridhaan)
Allah dan rasul-Nya, maka
hijrahnya itu ke arah (keridhaan)
Allah dan rasul-Nya. Barangsiapa
hijrahnya karena (harta atau
kemegahan) dunia yang dia
harapkan, atau karena seorang
wanita yang ingin dinikahinya,
maka hijrahnya itu ke arah yang
ditujunya"(Al-bukhari, 2002)

Lafadz (إنما) di dalam hadis berfaedah hasr (meringkas), yang mana artinya bahwa segala bentuk perbuatan itu hanya dinilai sesuai dengan niatnya. Maka ketika suatu perbuatan tidak disertai dengan niat, perbuatan tersebut tidak akan bernilai sehingga tidak akan mendapatkan pahala dari Allah SWT (An-nawawi, 1929).

Ketiga, batasan yang berhubungan dengan kadar konsumsi. Dalam melakukan kegiatan infak konsumsi, hendaknya konsumen muslim berkonsumsi sesuai kadar kebutuhannya, yaitu tidak melampaui batas dan tidak juga terlalu menahan diri. Hal tersebut telah dijelaskan dalam surat Al-Furqan ayat 67:

"Dan orang-orang yang apabila membelanjakan (harta), mereka tidak berlebihan, dan tidak (pula) kikir, dan adalah (pembelanjaan itu) di tengah-tengah antara yang demikian. "
Ayat di atas menjelaskan dan menganjurkan keadilan (tawassut) dalam mentasarrufkan atau membelanjakan harta, tidak berlebihan dan tidak terlalu menahan. Dalam pemabahasan kebutuhan, peneliti juga telah menyinggung ayat ini, di mana At-Tabarī (2001) memberikan suatu batasan mengenai israf dan taktir. Israf merupakan suatu perbuatan konsumsi yang melampaui batas sehingga menyebabkan tubuh lemah dan pada akhirnya berdampak pada kemalasan beribadah kepada Allah, seperti makan makanan di atas batas kenyang. Sedangkan taktir adalah perbuatan konsumsi yang terlalu menahan diri (pelit) dalam berkonsumsi.

Setiap orang berhak mendapatkan fasilitas yang baik dan layak disetiap pemenuhan kebutuhan nya sehari-hari, baik kebutuhan pangan, sandang ataupun papan. Dalam Islam tidak ada larangan bagi siapa saja untuk memakai baju bagus, makan makanan yang lezat atau memiliki rumah bagus. Islam menekankan umat manusia untuk tidak terlalu menahan diri dalam membelanjakan hartanya dalam memenuhi kebutuhan. Bahkan Islam mewajibkan setiap individu untuk menfasilitasi dirinya dan keluarga dengan fasilitas terbaik dalam memenuhi kebutuhannya selama tidak melewati batas (israf) yang dapat melalaikannya beribadah kepada Allah. Allah senang ketika melihat hambanya berada dalam kenikmatan yang Allah telah berikan kepada mereka. batasan ini telah disinggung dengan pemaparan secara rinci dipembahasan konsep kebutuhan.

Keempat, batasan dalam hal investasi. Setiap pelaku ekonomi muslim dituntut untuk tidak bergantung kepada orang lain, seperti berhutang dan memintaminta. Pelaku ekonomi yang baik akan selalu bisa melihat dan mempersiapkan apa yang kemungkinan terjadi di masa yang akan datang. Berinvestasi merupakan sarana yang tepat bagi pelaku ekonomi dalam mempersiapkan segala hal yang kemungkinan terjadi dimasa depan agar tidak terjerumus dalam bunga bank yang 
terindikasi riba. Di dalam beberapa ayatayat yang menyebutkan lafadz infak, dipahami secara implisit mengenai dianjurkannya investasi dalam Islam. Diantaranya surat Al-Baqarah ayat 3:

"(yaitu) mereka yang beriman
kepada yang ghaib, yang
mendirikan shalat, dan
menafkahkan sebahagian rezeki
yang Kami anugerahkan kepada
mereka"

Allah $\begin{array}{r}\text { Ayat di atas adalah bagaimana } \\ \text { menyampaikannya }\end{array}$ menggunakan kalimat "ومما رزقناهم ينفقون". Lafadz "من" dalam bahasa arab merupakan huruf jar yang berfaedah menujukkan sebagian dari sesuatu (للتبعيض). Hal ini berarti bahwa infak yang dianjurkan dalam Islam adalah infak dari sebagian harta yang di rejekikan Allah. Maka sebagian harta diinfakkan dan sebagiannya lagi disimpan ataupun dinvestasikan untuk keperluan masa depan. Hal tersebut juga telah dilakukan Rasulallah SAW yang mana beliau menyimpan pangannya untuk jatah tahun berikutnya. Al-Qarḍāwī (1995) berpandangan bahwa investasi semacam ini sangat bagus sekali bagi umat Islam di masa depan ketika ada kebutuhan mendesak agar terhindar dari hutang yang mengandung unsur riba.

\section{KESIMPULAN}

Berdasarkan hasil penelitian, maka dapat disimpulkan bahwa Infak konsumsi merupakan kegiatan membelanjakan harta dalam upaya memenuhi kebutuhan sehingga mendapatkan maslahah dunia dan akhirat. Dalam kegiatan infak konsumsi, konsumen harus memperhatikan batasanbatasan yang mencakup dua komponen penting, yaitu hukum Islam dan etika.

Model infak menjelaskan tingkatan prioritas yang menjadi teori pengambilan keputusan konsumen dalam membelanjakan hartanya. Seorang konsumen harus memenuhi kebutuhannya sendiri. Kemudian membayar hutang ataupun segala bentuk tanggungan yang diwajibkan kepadanya. Setelah itu, konsumen harus memenuhi kebutuhan keluarga yang menjadi tanggung jawabnya (nafakah). Selanjutnya adalah membayar zakat apabila memebuhi syarat wajib zakat (haul dan nisab). Kemudian apabila tidak memenuhi syarat zakat, maka sebagian harta bisa dishadakahkan. Dan terkahir adalah investasi ataupun menabung demi kehidupan masa depan.

Selanjutnya tujuan berkonsumsi dalam infak konsumsi mencakup dua komponen; kepuasan secara material (utility) dan kesejahteran akhirat (pahala dan surga). Kedua komponen tersebut terkandung dalam suatu istilah yang disebut dengan "maslahah".

\section{DAFTAR PUSTAKA}

Al-Bukhari,Muhammad Bin Ismail. (2002). As-Ṣah̄h Al-Bukhārī. Dar Ibnu Katsir.

An-Nabhānī, T. (2004). Niz̄ām Al-Iqtiṣādī Fūl Islām. Darul Ummah.

An-Nawawi, S. (1929). Sharkh An-Nawawī Alā Șahīh Muslim.

Ar-Rāzī, F. (1981). Mafātih Al-Ghayb. Dar Alfikr.

At-Tabarī, I. A. -J. (2001). Jāmi’ Al-Bayāni F̄̄ Ta'wāl Al-Qur'̄ini. Hajr.

At-Tirmidh̄̄,Muhammad Bin Isa. (2011). Sunan At-Tirmidhī. Dar Ibnu Jauzi.

Az-Zabīdī, M. (N. D. ). Tāj Al- 'Arūs 'An Jawāhir Al-Qāmūsī. 
Daud,Sulaiman Abi. (2009). Sunan Abi Daud. Pdf. Dar Risalah Alamiyah.

Hans, P. S. S. D. W. D. N. (1993). Ekonomi. Erlangga.

Kahf, M. (2012). Infak In The Islamic Economic System Monzer Kahf Infak In The Islamic Economic System.

Karim, A. (2012). Sejarah Pemikiran Islam (9th Ed. ). Pt Rajagrafindo Persada.

Khaf, M. (1995). Ekonomi Islam: Telaah Analitik Terhadap Fungsi Sistem Ekonomi Islam. Pustaka Pelajar.

Khan, F. (2013). An Alternative Approach To Analysis Of ConsumerBehaviour: Need For Distinctive Islamic Theory. Journal Of Islamic Business And Management, 3(2), 15-49.

Manan, M. A. (1997). Ekonomi Islam: Teori Dan Praktik. PT Dana Bhakti Prima Yasa.

Mankiw, N. G. (2003). Teori Makro Ekonomi. Erlangga.

Muhadjir, N. (1996). Metodologi Penelitian Kualitatif.

Muhammed,Mustafa Omar. (2011). Economic Consumption Model Revisited: Infak Based On Al- Shaybani’s Levels Of Al-Kasb. IIUM Journal Of Economics And Management.

Rahim, H. A. , \& Bahari, Z. (2018). Keynes' Consumption Theory: A Reevaluation According To The Islamic Perspective. Global Journal Al-Thaqafah, 8(1), 7-13.

Salleh, M. S. (2011). Islamic Economics Revisited : Re-Contemplating Unresolved Structure And Assumptions. 8th International Conference On Islamic Economics And Finance. Doha, Qatar.

Yūsuf Al-Qarḍāwī. (1995). Dawrul Qiyam Wal Ahklāq Fūl Iqtiṣād Al-Islāmī, Nizāam AlIqtiṣādī Fūl Islām (1st Ed. ). Maktabah Wahbah. 